\title{
Technology of Polish copper ore beneficiation - perspectives from the past experience
}

\author{
Andrzej Wieniewski ${ }^{1}$, and Bozena Skorupska ${ }^{1, a}$ \\ ${ }^{1}$ Institute of Non-Ferrous Metals, ul. Sowinskiego 5, 44-100 Gliwice, Poland
}

\begin{abstract}
The paper describes the main types of existing copper deposits in the world and the most common enrichment technologies. The characteristic elements of the current flowsheet of the Polish ore beneficiation were discussed together with the reasons for using them. The paper presents a perspective flowsheet based on more than 50-years of experience in beneficiation of Polish copper ore. The main elements of proposed technology are: leaving in justified cases the division of ore into fractions of increased sandstone and carbonate ores content, flotation in the milling circuit as part of the effective preparation of the ore to rougher flotation, intensive rougher flotation, classic cleaning system, processing of the middlings with grinding system in new type mills, classification and flotation with outlet of final tailings.
\end{abstract}

\section{Introduction}

Polish copper ore deposits are of sedimentary type, quite commonly found in the world. However, they have different mineralogical-petrographic and physicochemical properties. The similarities occur only with the ores from the region of Lusatia and Mansfeld (Germany), currently not under exploitation. There are also some similarities with respect to the White Pine (US) and in a lesser extent to Dzheskazgan (Kazakhstan) ore deposits.

Under these conditions, during the technology development of Polish copper ores in the sixties of the last century, it was difficult to fully follow the experience of foreign facilities. These technologies were developed by the Institute of Non-Ferrous Metals and tested in the Experimental Department of KGHM Polska Miedz S.A., under which BP Bipromet and ZBiPM Cuprum performed technical design.

Currently, for the same reasons, not all the achievements in the beneficiation technology in the world can be applied in the Polish enrichment plants. Limitations are also imposed by existing technical and organizational requirements in individual enrichment plants.

In the world, among the total amount of produced copper, about $90 \%$ is recovered from the ore containing sulphidic minerals. The main method of beneficiation is flotation, while flotation enrichment flowsheets are relatively simple. In most cases, the particle size of the ore directed to beneficiation is coarse (degree of comminution $K_{80 \%}=120-200 \mu \mathrm{m}$ ), flotation time is short and circuits of middlings are simple. The concentrates of rougher flotation to are usually reground to liberate copper sulphides from other easy-floating minerals such as pyrite.

\footnotetext{
${ }^{a}$ Corresponding author: bozenas@imn.gliwice.pl
} 
Each beneficiation flowsheet has its own specification resulting from the type of enriched ore, but it is also a reflection of the technique state and technology period in which arose $[1,2]$.

In the world, from the point of beneficiation process, the copper ore deposits can be divided into the following main types $[3,4]$ :

- porphyry ores occur very often, and it is estimated that more than $60 \%$ of the copper production comes from this deposit type. They are mainly copper-containing ores and copper and molybdenum ores. Examples of porphyry deposits are Chuquicamata and La Escondida (Chile), Bingham Canyon (US), Grasberg (Indonesia)

- deposits of copper-bearing pyrite occur among volcanic and volcanic-sedimentary rocks. The composition of ores is variable, usually polymetallic with plenty of either pyrite or pyrrhotite. Examples are deposits in North America

- stratified deposits in sedimentary and metamorphic rocks. The economic significance of these deposits is high. The $\mathrm{Cu}$ deposits occur among the marine clay formations, marly less carbonate and sandy. Copper-bearing shales and copper-bearing sandstones are present in this deposits. Minerals create a sandstone binder, microscopic grains scattered in the claycarbonate rocks and veins. Examples of stratified deposits are Nchanga (Zambia), Kupferschiefer (Poland), White Pine (US)

- $\quad$ other sulphe ores of polymetallic type. They include for example $\mathrm{Cu}-\mathrm{Zn}-\mathrm{Pb}, \mathrm{Cu}-\mathrm{Mo}, \mathrm{Cu}-\mathrm{Ni}$, $\mathrm{Cu}-\mathrm{Pb}$ ore etc.

Figure 1 shows an example of the most common porphyry copper ore type beneficiation flowsheet. Porphyry ores, although generally contain small amount of copper below 1\%, belong to easy-to-float ores, and the obtained concentrates are about $30 \%$ of $\mathrm{Cu}$. Technological flowsheets for porphyry copper ores are simple. A typical flowsheet is shown in Fig. 1 [5]. It includes the following circuits:

- ore preparation for flotation

- flotation in the milling circuit - rougher flotation

- classification and regrinding of rougher flotation concentrate

- cleaning flotation with the outlet of the second component of the final tailings from the I cleaning flotation.

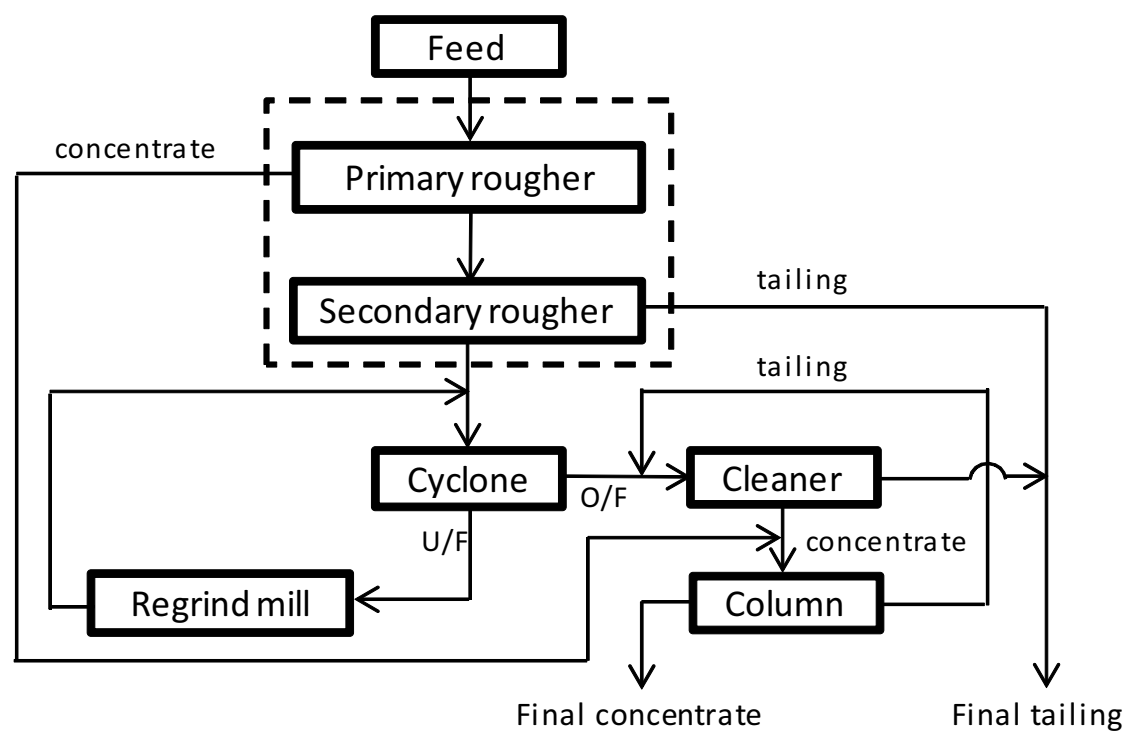

Figure 1. A typical flowsheet used in the flotation process of porphyry copper [5]. 
In the case of copper-molybdenum ores the flowsheet is more complex, especially when the collective concentrate of copper and molybdenum is heat treated before separation of copper from molybdenum.

\section{Beneficiation technology of Polish copper ores - past experience and perspective}

\subsection{Characteristics of the ores}

The copper ore exploited and processed at KGHM Polska Miedz S.A. plants has a complex chemical composition and unfavourable mineralization. It is characterized by high variability in susceptibility to enrichment. The main reason is that the ore occurs in three lithological varieties, namely carbonate, shale and sandstone, with different physical and chemical properties. The shale ore, the richest among all lithological variations (fractions), is characterized by the worst beneficiation. Its share in the deposit is steadily increasing, but is variable, even within the same mining area. This directly affects the basic parameters of the deposit, i.e. the share of individual lithological fractions, copper content, and therefore the characteristics of the exploited ore beneficiation. Illustrations of the problem are made based on groove samples from the prospective mine areas, maps of the metal recovery in concentrate in the study area of deposits [6] (Fig. 2).

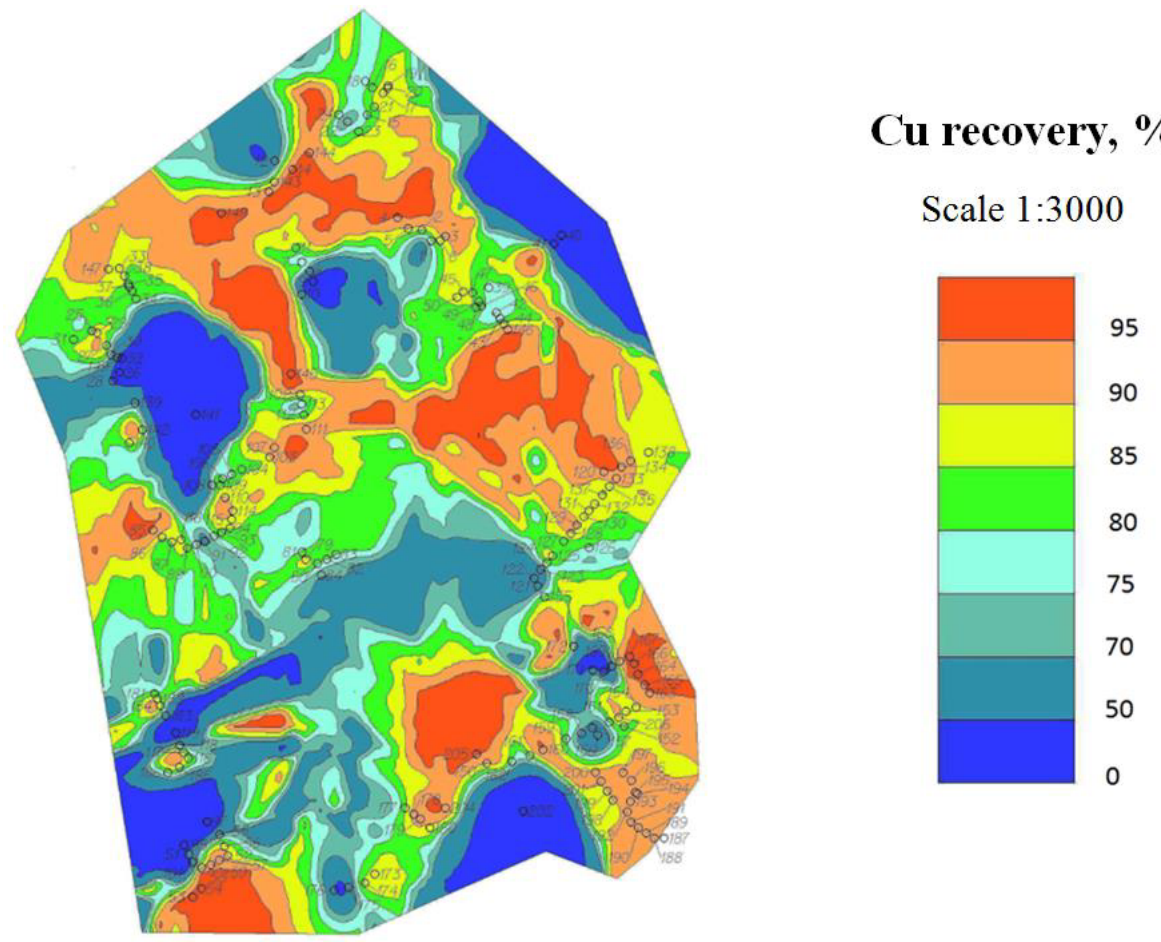

Figure 2. Values of the copper recovery possible to obtain for the studied mining area.

Skorupska et al. [6] described variations in copper content in the area of the deposit. The attention was also paid to a frequent lack of correlation between the content of copper in the deposit and ore beneficiation. It is found that with the progress of exploitation and depletion of ore resources, the metal content in the ore was decreasing and the properties of ore were deteriorating (Table 1). 
Table 1. Copper $(\mathrm{Cu})$ and organic carbon $\left(\mathrm{C}_{\mathrm{org}}\right)$ contents in the ore directed to beneficiation in last years.

\begin{tabular}{|c|c|c|c|c|c|c|}
\hline \multirow{2}{*}{ Year } & \multicolumn{2}{|c|}{ Lubin concentrator } & \multicolumn{2}{|c|}{ Polkowice concentrator } & \multicolumn{2}{|c|}{ Rudna concentrator } \\
\hline & $\mathrm{Cu}, \%$ & Corg, \% & $\mathrm{Cu}, \%$ & Corg, \% & $\mathrm{Cu}, \%$ & $\mathrm{C}_{\text {org, }} \%$ \\
\hline 1995 & 1.34 & 0.76 & 1.75 & 1.14 & 1.90 & 0.64 \\
\hline 1996 & 1.36 & 0.65 & 1.86 & 1.10 & 2.06 & 0.71 \\
\hline 1997 & 1.37 & & 1.94 & 0.62 & 2.10 & 0.69 \\
\hline 2000 & 1.17 & 0.87 & 1.96 & 1.07 & 2.20 & 0.76 \\
\hline 2001 & 1.14 & 1.30 & 198 & 0.98 & 2.14 & 0.74 \\
\hline 2002 & 1.32 & 1.40 & 1.99 & 1.22 & 2.36 & 1.14 \\
\hline 2003 & 1.30 & 1.06 & 2.00 & 2.00 & 2.31 & 0.98 \\
\hline 2004 & 1.28 & 1.62 & 2.03 & 1.66 & 2.23 & 1.49 \\
\hline 2010 & 1.03 & 0.85 & 1.82 & 0.95 & 1.85 & 0.75 \\
\hline 2011 & 0.96 & 0.69 & 1.80 & 0.92 & 1.84 & 0.70 \\
\hline 2012 & 0.91 & 0.76 & 1.81 & 0.85 & 1.79 & 0.74 \\
\hline 2013 & 0.91 & 0.84 & 1.75 & 0.80 & 1.80 & 0.73 \\
\hline
\end{tabular}

\subsubsection{Problem of organic components}

Organic components appearing in the Polish copper ores, mainly in a shale layer, are the main cause of difficulties occurring in the flotation process. Their presence in ores essentially determine the course of the enrichment process and the results of this process. An example of the impact of organic carbon on the technology results expressed as the recovery of copper in concentrate, is shown in Fig. 3 [6].

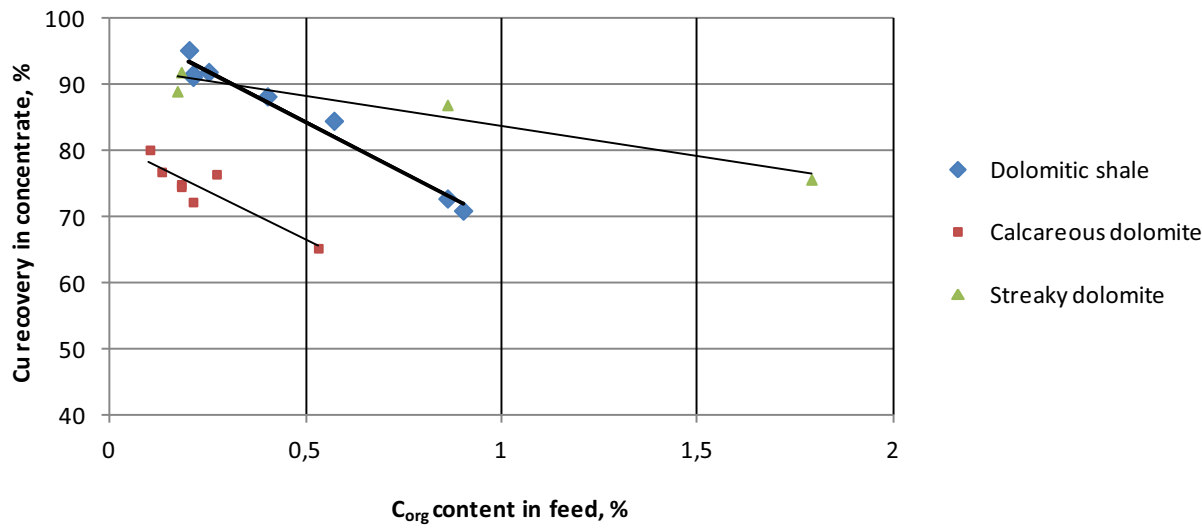

Figure 3. Example of the impact of organic carbon content on the recovery of copper in concentrate [6].

In the view of the negative effect of organic compounds in the flotation process for years it is tried to find ways to reduce their negative impact on this process. One of the methods were attempts to float these components before rougher flotation [7]. This type of flotation, so called preflotation, exists in several enrichment plants in the world, i.e. Mt. Isa, Red Dog in Australia for graphitic carbon preflotation, before flotation of copper, lead and zinc minerals. In the case of Polish copper ores, this kind of flotation did not bring satisfactory results and has not found practical application. Besides the negative impact on the flotation process, the problem is also with the content of organic components in the produced copper concentrates. Currently, this problem is partially solved by the use of segregating flotation and production of two concentrates with different organic carbon contents 
directed to various metallurgical processes [8]. After elimination of a shaft furnace, in which the concentrate with a high content of organic components is processed, necessary will be roasting the part of the concentrate prior to directing it to metallurgical processes.

\subsection{Characteristics of beneficiation technology}

The complex lithological, mineral and chemical composition of Polish copper ores is a cause of problems during processing these deposits and force to use more complex technological systems. Moreover, different particle size distributions of minerals in the individual lithological variations cause the need of different grinding degree to liberate minerals during preparation for flotation. Therefore, a flowsheet for mixed ore enrichment was introduced, covering separation into fractions with increased share of sandstone and dolomite-shale ore and subsequent enrichment in separate lines [9]. A block diagram of mixed ore beneficiation processed in the Rudna area is shown in Fig. 4 [10].

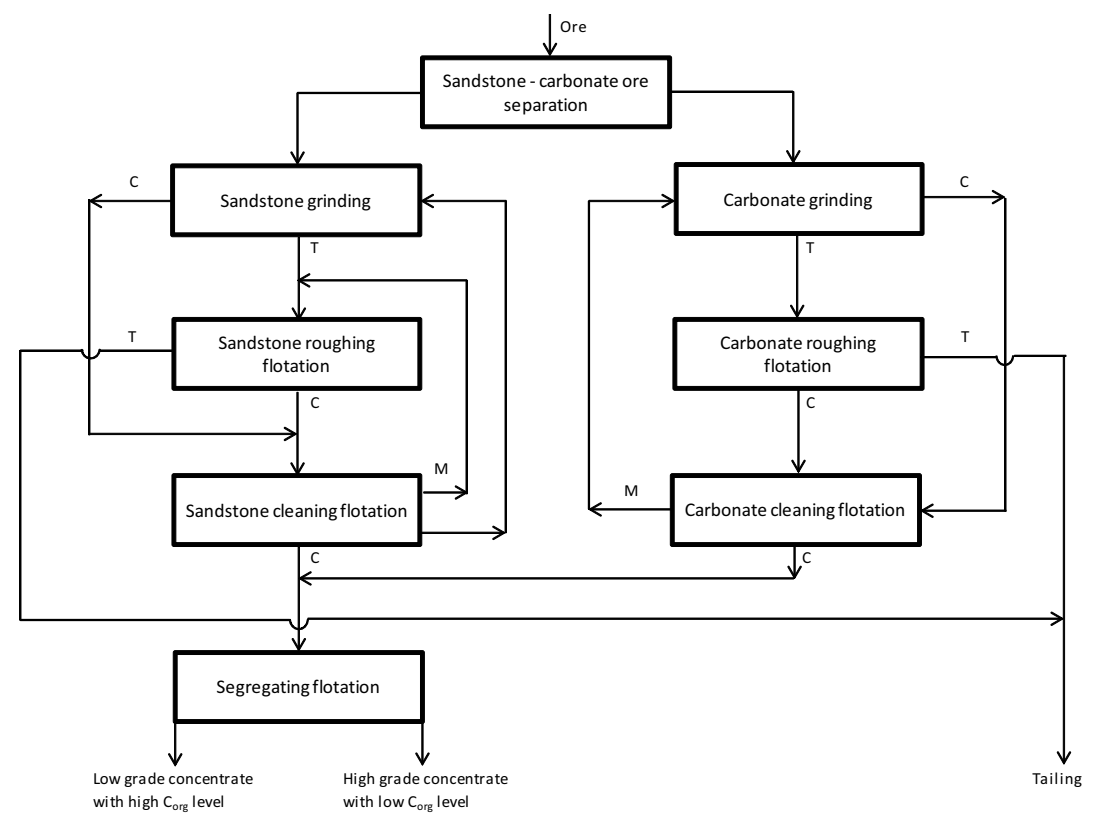

Figure 4. Processing of mixed sandstone-carbonate ore.

The flowsheet includes:

a) beneficiation of dolomite-shale ore, which consists of:

- a second grinding stage, due to high requirements for grinding of carbonate- shale ore sufficient to liberate sulphide minerals

- flotation in the milling circuit

- rougher flotation and three-stage cleaning

- regrinding the middlings; in the case of beneficiation in the Lubin area flotation in the circuit of middlings regrinding is also possible

b) beneficiation of sandstone ore, which consists:

- classification and regrinding

- flotation in the milling circuit

- rougher flotation along with two-stage cleaning 
c) combined concentrate derived from the enrichment line of sandstone and carbonate fraction in the Rudna area is subjected to segregating flotation, by which the concentrate so-called low calorie with high copper content and relatively low organic carbon content and high calorie with lower copper content and a high organic carbon content is obtained.

Table 2. Comparison of enrichment indexes in different years.

Polkowice concentrator

\begin{tabular}{|c|c|c|c|c|c|}
\hline \multirow{2}{*}{ Year } & \multicolumn{2}{|c|}{ Feed } & \multicolumn{2}{|c|}{ Concentrate } & Recovery \\
\hline & $\mathrm{Cu}, \%$ & $\mathrm{C}_{\mathrm{org}}, \%$ & $\mathrm{Cu}, \%$ & $\mathrm{C}_{\text {org }}, \%$ & $\mathrm{Cu}, \%$ \\
\hline 1995 & 1.75 & 1.14 & 26.94 & 6.57 & 88.58 \\
\hline 1996 & 1.83 & 1.10 & 26.70 & 6.37 & 88.65 \\
\hline 1997 & 1.94 & 0.62 & 25.74 & 7.74 & 88.80 \\
\hline 2001 & 1.98 & 0.98 & 27.24 & 7.28 & 87.40 \\
\hline 2002 & 1.99 & 1.22 & 27.20 & 8.47 & 87.62 \\
\hline 2003 & 2.00 & 2.00 & 27.12 & 8.04 & 87.73 \\
\hline 1010 & 1.80 & 0.95 & 24.13 & 8.07 & 87.55 \\
\hline 2011 & 1.80 & 0.92 & 23.70 & 8.57 & 87.44 \\
\hline 2012 & 1.81 & 0.85 & 24.58 & 8.25 & 87.42 \\
\hline
\end{tabular}

Rudna concentrator

\begin{tabular}{|c|c|c|c|c|c|}
\hline \multirow{2}{*}{ Year } & \multicolumn{2}{|c|}{ Feed } & \multicolumn{2}{|c|}{ Concentrate } & Recovery \\
\hline & $\mathrm{Cu}, \%$ & $\mathrm{C}_{\text {org }}, \%$ & $\mathrm{Cu}, \%$ & $\mathrm{C}_{\text {org }}, \%$ & $\mathrm{Cu}, \%$ \\
\hline 1995 & 1.90 & 0.64 & 28.40 & 7.26 & 88.97 \\
\hline 1996 & 2.06 & 0.71 & 28.57 & 7.45 & 89.31 \\
\hline 1997 & 2.06 & 0.69 & 28.07 & 7.52 & 89.98 \\
\hline 2001 & 2.14 & 0.74 & 28.88 & 6.18 & 90.12 \\
\hline 2002 & 2.36 & 1.14 & 30.42 & 6.82 & 89.74 \\
\hline 2003 & 2.31 & 0.98 & 30.55 & 6.33 & 89.91 \\
\hline 2010 & 1.79 & 0.73 & 26.26 & 7.92 & 89.95 \\
\hline 2011 & 1.84 & 0.75 & 26.41 & 7.93 & 89.71 \\
\hline 2012 & 1.79 & 0.70 & 26.11 & 7.92 & 90.12 \\
\hline
\end{tabular}

Lubin concentrator

\begin{tabular}{|c|c|c|c|c|c|}
\hline \multirow{2}{*}{ Year } & \multicolumn{2}{|c|}{ Feed } & \multicolumn{2}{|c|}{ Concentrate } & Recovery \\
\hline & $\mathrm{Cu}, \%$ & Corg, \% & $\mathrm{Cu}, \%$ & $\mathrm{C}_{\text {org }}, \%$ & $\mathrm{Cu}, \%$ \\
\hline 1995 & 1.34 & 0.76 & 18.97 & 7.33 & 89.86 \\
\hline 1996 & 1.36 & 0.65 & 18.67 & 6.74 & 89.98 \\
\hline 1997 & 1.37 & 0.84 & 18.45 & 7.66 & 90.05 \\
\hline 2001 & 1.14 & 1.30 & 17.13 & 7.25 & 86.70 \\
\hline 2002 & 1.32 & 1.40 & 17.33 & 8.30 & 87.15 \\
\hline 2003 & 1.30 & 1.06 & 17.79 & 8.67 & 87.01 \\
\hline 2010 & 1.02 & 0.95 & 14.50 & 7.61 & 86.69 \\
\hline 2011 & 0.96 & 0.69 & 13.90 & 7.33 & 86.98 \\
\hline 2012 & 0.91 & 0.76 & 14.05 & 7.88 & 88.98 \\
\hline
\end{tabular}

Currently produced copper concentrates contain from 14 to $14.5 \%$ copper (Lubin area) to $26.4 \%$ (Rudna area). In the past, the contents were at a higher level, on average, for all plants, about 26 to $27 \%$ (from 2001 to 2003 year). The higher copper content in the produced concentrate favoured lower 
content of organic carbon. Table 2 shows a comparison of enrichment indices in different years for three plants Rudna, Polkowice and Lubin. In spite of processing the ore of difficult beneficiation the enrichment indices are at good level and the overall evaluation, carried out by SGS company from Lakefield (Canada) in 2007, of the used technology can be positive.

\subsubsection{Flotation in a milling circuit}

A special role in the technology of Polish copper ore beneficiation belongs to flotation in the milling circuit [11]. The main task of this flotation is to remove from the classification-grinding system the concentrate to cleaning flotation. It prevents overgrinding of liberated copper sulphides. Otherwise, these minerals accumulate in the hydrocyclones underflow due to the higher specific gravity in relation to the waste rock. Then, they pass unnecessary fragmentation, sometimes to the level preventing effective flotation. This makes that in greater amount they get to final tailings. The effects of flotation in the milling circuit is well illustrated by the analysis of the copper content in the material recycled to the mill as a function of particle size distribution (Fig. 5) [12].

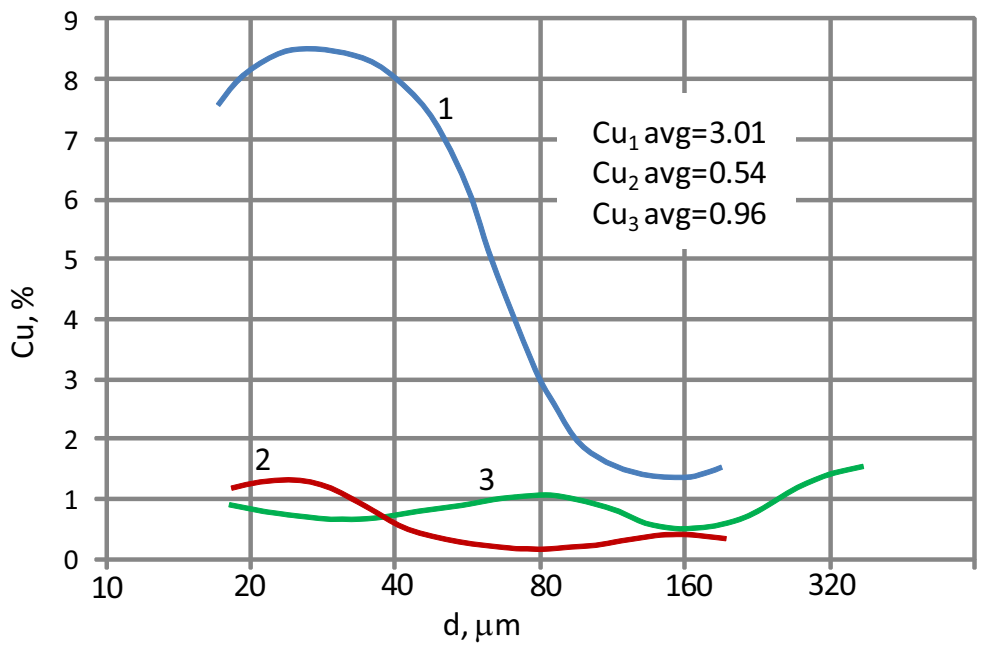

Figure 5. Copper content in size distribution, where 1 is the product recycled to mill without using flotation in the milling circuit, while 2,3 are the products recycled to mill using flotation in the milling circuit.

Flotation in the milling circuit can be carried out in conventional flotation machines. It can also be carried out in a special construction machines. Machines of special construction such as IZ- 9S, IZ$16 \mathrm{~S}$ types worked in the nineties of the last century in all areas of ore enrichment plants [13]. The feed for these type of machines was underflow product of either ball mills or hydrocyclones. Therefore, they worked with a high density of the slurry and under the relatively coarse particle size.

The aim of flotation, as it was in the classic flotation in grinding circuit, was to remove the liberated copper sulphides in the primary beneficiation phase. The obtained concentrates were of high quality corresponded to the quality of the final concentrate. It had a favourable effect on circulation of middlings and stable production of the final concentrate.

It is worth to emphasize that the low organic carbon content in concentrates was obtained in this flotation. In the case of the concentrate from the Polkowice concentrator, content of organic carbon was only $1.2-2.0 \%$ with a $36-47 \%$ of copper content in the concentrate. This was a factor for stabilizing an organic carbon content on the lower level in the produced final concentrate. Table 3 presents the test results of flash flotation carried out in flotation machines IF-19S in the area of Rudna and Polkowice in years 1998-1999. 
Table 3. Flotation results in milling circuits in machines IF-19S and IF-9S.

\begin{tabular}{|l|l|l|l|}
\hline $\begin{array}{l}\text { Product, component } \\
\text { content \% }\end{array}$ & $\begin{array}{l}\text { Sandstone fraction } \\
\text { Rudna concentrator }\end{array}$ & $\begin{array}{l}\text { Carbonate fraction } \\
\text { Rudna concentrator }\end{array}$ & $\begin{array}{l}\text { Polkowice } \\
\text { concentrator }\end{array}$ \\
\hline Feed, $\mathrm{Cu} \%$ & $0.9-1.20$ & $2.45-3.48$ & $2.5-2.92$ \\
\hline $\begin{array}{c}\text { Concentrate } \mathrm{Cu} \% \\
\mathrm{C} \text { org. \% }\end{array}$ & $34.34-44.2$ & $31.61-41.9$ & $35.58-47.04$ \\
\hline Tailing $\mathrm{Cu} \%$ & - & - & $1.2-2.0$ \\
\hline
\end{tabular}

In the years 2001-2003 (Table 1) high grade concentrates were produced. Despite the high organic carbon content in the feed the content of organic carbon in the produced concentrates was at an acceptable level. It should be associated with a positive role of flotation in the milling circuit. Despite achieving good technological results because of operational difficulties, flotation in these machines was eliminated. Currently, flotation in the milling circuit is performed in the standard flotation machines of IF type. An important consequence of the correct operation of flotation in the milling circuit should be decopperization of the feed for rougher flotation. As a result, the copper content in the feed in this flotation should be significantly lower than in the raw ore. This ensures a low copper content in the rougher flotation tailing, and thus a high recovery in the whole process of beneficiation.

\subsubsection{Rougher flotation}

Rougher flotation in the technology of Polish ores beneficiation, differently than porphyry ores, is characterized by long flotation time. The system of rougher flotation has a significant impact on the final indexes of enrichment, because it directly determines the losses of copper to the tailings. It also affects the quality of the final concentrate. This quality increases as copper content is increasing in the concentrate from rougher flotation. Minimizing the losses of copper in the tailings, especially in the coarse classes can be achieved by optimizing for instance classification the feed for rougher flotation in hydrocyclones.

\subsubsection{Role of middlings in a beneficiation process}

One of the causes of the technological problems of the beneficiation process are circulating in current circuits so-called middlings (I cleaning tailings). The question of middlings and the scale of the problems created by them is still unsolved. It is estimated that in the middlings circulate about $30-35 \%$ of the ore by weight carrying $30-35 \%$ of copper for the most part in the form of not liberated copper sulphides, and about $30-40 \%$ organic carbon [14].

In recent years, in all enrichment plants at KGHM Polska Miedz S.A., despite decreasing of copper content in the ore directed to beneficiation, there is increased copper and organic carbon content in the middlings. This phenomenon is a disadvantage, especially in respect of the rougher flotation operation. The basic chemical characteristics of middlings from Rudna and Polkowice areas is presented below based on the available data from 2015:

Rudna area:

- sandstone middlings $-\mathrm{Cu}-$ approx. $6 \%, \mathrm{C}_{\text {org. }}-$ approx. $5 \%$

- carbonate middlings $-\mathrm{Cu}-13.5-14 \%, \mathrm{C}_{\text {org. }}-$ approx. $6 \%$

Polkowice area:

- middlings of II technological line $-\mathrm{Cu}-$ approx. $6 \% ; \mathrm{C}_{\text {org }}-$ approx. $8 \%$.

Current processing of middlings consists of their regrinding in the cylpebs mills, and then classification in hydrocyclones and recycling to rougher flotation. Multiple recycling of middlings results in accumulation of copper in them, but also other adverse components of ore, including organic carbon, clay minerals etc. This has a negative impact on the work of rougher flotation and achieved final indices of the enrichment process. 


\section{Beneficiation technology - future from the past experience}

Due to the unavoidable deterioration of mined ores the natural tendency will be lowering of enrichment indexes. Therefore, an essential element is the analysis of the possible measures to inhibit these negative trends. In recent years, a lot of modernization activities in enrichment plants were made, e.g. exchanged flotation machines, introduced a number of solutions in the field of flotation machine control (FloVis system), continues modernization of classification systems in hydrocyclones.

In addition to the modernization efforts including implementation of new devices also should take action to adapt flowsheets to changing characteristics of ore and metallurgical requirements. The perspective technology should take the best of ore beneficiation technology in the world, but also take into account more than 50 - years of the Polish plants working experience.

The future technology should include the following main elements (Fig. 6):

a) preparation of ore for flotation taking into account solutions that have the most favourable industrial references. The traditional three-stage crushing in either cone crushers or SAG mills was used [15]. The use of SAG mills could afford a marked reduction in the number of operations and unit processes compared to multi-stage grinding scheme in cone crushers with simultaneous possibility of obtaining a finer feed to ball mills. The way of ore preparation for flotation is of particular interest of KGHM Polska Miedz S.A.

b) processing in plant a mixed ore with a relatively constant proportion of sandstones and carbonates is worth to consider to keep separation into fractions with a higher share of sandstones and carbonates, with their separate processing. This allows to adjust the operating parameters of individual systems (grinding, flotation, middlings processing) to the diverse requirements in terms of beneficiation of separate fractions

c) it is necessary to increase the intensity of flotation in the milling circuit. It is an essential part of fulfilling the requirement of preparing the feed for rougher flotation (decopperization of the feed) and stabilizing production of the final concentrate with reduced content of organic carbon. This flotation may be performed in the standard flotation machines by mounting the froth crowder to reduce the yield of the concentrate

d) change of the middlings processing by grinding in mills of a new type i.e. Vertimill ${ }^{\circledR}$, IsaMill or other (magnetic), and then flotation in open cycle with tailings outlet - the second component of the final tailings. Vertimill ${ }^{\circledR}$ and IsaMill for many years were used in industries for very fine grinding. Currently, the mills are used in non-ferrous metal industry, generally for concentrates regrinding. It is believed that the use of fine grinding mills would enable improvements in liberation of sulphides from fine-mineralised ore and improve the flotation results

e) implementation of cleaning in two- and tree-stages system

f) changing in the way of dewatering the final concentrate by carrying out the process at increased temperatures, enabling to reduce the water content to a level of $8-8.5 \%$ and elimination of the drying process.

Thinking about future technologies it cannot be forgotten the importance of the development of machinery construction and processing equipment, new flotation reagents, including activators, containing in its composition new functional groups for improved adsorption of either existing or new collectors on the surface of copper sulphide. Processing is an important element in miningmetallurgical process for copper production. The final indices of the enrichment process, i.e. recovery and quality of concentrate, should be related not only to beneficiation of ore, but also take into account the economic balance of the whole production line including a certain level of stock market prices of copper and silver. 


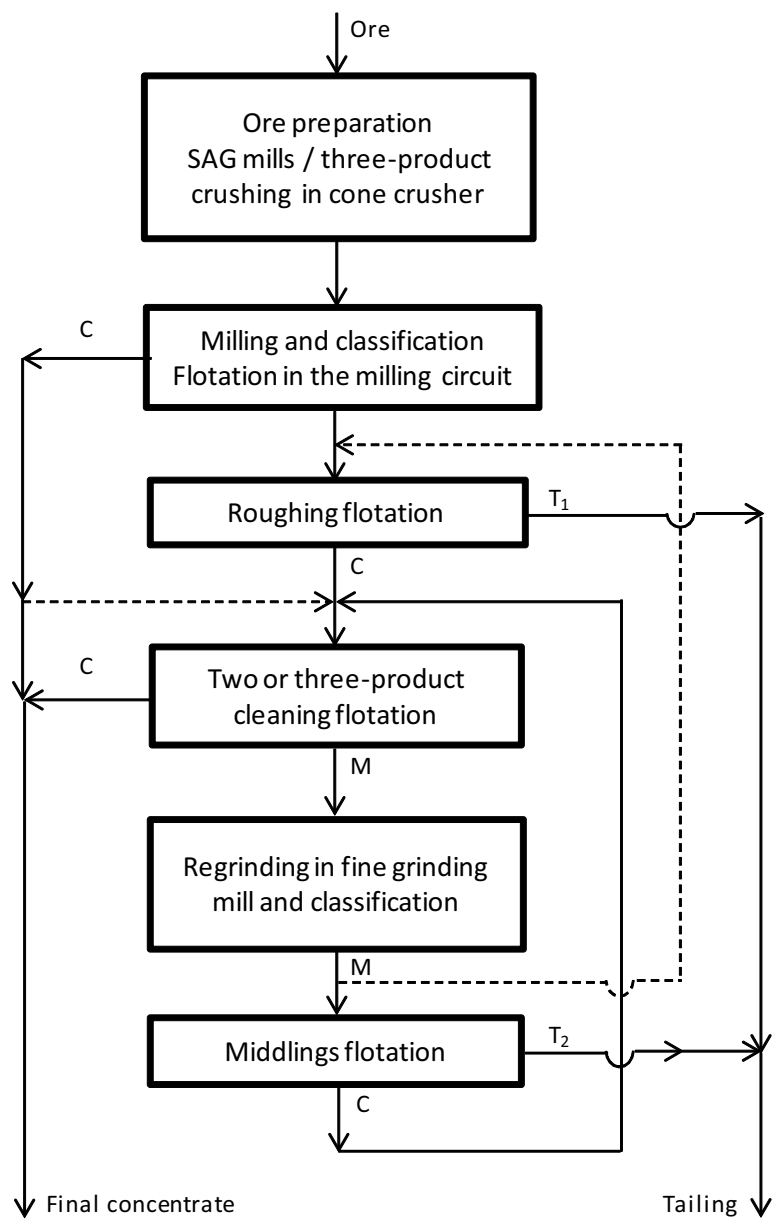

Figure 6. Proposed flowsheet for mixed ore processing at KGHM Polska Miedz S.A.

\section{Summary}

A beneficiation technology of Polish copper ores is developed to their specific properties. In different periods of application high indices of enrichment were achieved. Gained experience of the past allows to develop the technologies of the future. This does not mean omitting new solutions, particularly in the field of machinery and equipment, process control and the introduction of new flotation reagents. It is important to treat processing as an important element of the mining-metallurgical process for copper production. Metallurgy sets specific requirements to produced concentrate, the achievement of which constitute a separate optimizing tasks. Future processing should consists of technologies that use more than fifty years potential of knowledge in the field of concentrates production for certain pyro- and hydrometallurgical processes ensuring comprehensive recovery of contained in them metals.

\section{References}

1. S. M. Bulatovic, D.M. Wyslouzil, Miner. Eng., 11(4) (1998)

2. W. Blaschke, Z. Blaschke, Inzynieria Mineralna, 8(2) (2008) 
3. A. Bolewski, Surowce mineralne swiata, (Wydawnictwo Geologiczne, Warszawa 1997)

4. S.M. Bulatovic, Handbook of flotation reagents (2007)

5. B.A. Wills, T. Napier-Munn, Mineral processing technology (2005)

6. B. Skorupska, A. Wieniewski, N. Kubacz, Zastosowanie metod geostatystycznych do oceny zmiennosci wzbogacalnosci rudy (Monograph, 2013)

7. R. Bortel, J. Gramala, Z .Grzebieluch, IMN Report No. 1489 (1970)

8. B. Skorupska, A. Wieniewski, N. Kubacz, IMN Report No. 6956 (2011)

9. A. Wieniewski, S. Sobierajski, Stan aktualny oraz dalsze zamierzenia $w$ zakresie flotacji rudy miedzi w Zakladach Wzbogacania KGHM Polska Miedz S.A. (Lubiatow, 1996)

10. A. Wieniewski, in Proccedings of V Miedzynarodowa Konferencja Przerobki Rud Metali Niezelaznych ICNOP (1999)

11. A. Wieniewski, J. Dziadek, Ph.D. thesis (1983)

12. W. Madej, A. Wieniewski, S. Zienkiewicz, IMN Report No. 3 (1977)

13. E. Szczerba, J. Komorowski, B. Skorupska, in Proccedings of V Miedzynarodowej Konferencji Przerobki Rud Metali Niezelaznych ICNOP, (1999)

14. A. Luszczkiewicz, A. Wieniewski, Gorn. Geoinz., 3(1) (2006)

15. A. Grotowski, A. Szubert, W. Mizera, B. Mizera, Cuprum report (2009) 